\title{
JEKK
}

Jurnal Epidemiologi Kesehatan Komunitas

2 (1), 2017, 1-6

\section{Faktor yang Berpengaruh terhadap Kegagalan Pengendalian Diabetes Melitus Tipe 2 pada Pasien yang Berobat di PT. Askes Cabang Sampit Kabupaten Kotawaringin Timur}

\author{
Diana", Suharyo Hadisaputro ${ }^{* *}$, Heri Nugroho ${ }^{* * *}$ \\ "Dinas Kesehatan Kabupaten Kotawaringin Timur, "Politeknik Kesehatan Semarang, \\ ${ }^{* * *}$ Fakultas Kedokteran Universitas Diponegoro
}

\begin{abstract}
Background: Diabetes mellitus is a chronic disease characterized by blood glucose levels than normal, impaired metabolism of carbohydrates, fats and proteins caused by a deficiency of the hormone insulin relative or absolute. Control of blood sugar in people with DMT 2 is an essential requirement for delaying complications, in the community. DMT 2 risk factor is age, longsuffering, sex, education, socio-economic, knowledge, attitudes, practices, patterns of diet, obesity, how to take medication, exercise, family support, educate physicians and nutritionists. The purpose ofthe study describes some of the factors that influence the DMT2 control failure.

Methods: The study useda case-control design is reinforced by the qualitative study. The number of respondents was 122, including 61 cases and 61 controls taken by consecutive sampling. Analysis ofthe data using univariate, bivariate (chi-square) and multivariate (logistic regression). Results: Analysis of some factors that influence the attitude control DMT 2 (OR 34.4), exercise (OR 8.7), knowledge (OR 8,4), age (OR 5.9), family support (OR 5.2), how totake medication (OR 3.5). Various factors were not shown to significantly affect the failure to control type 2 diabetes mellitus are: Long suffering, sex, smoking, education, socio-economic, diet, obesity, stress/depression, education of physicians and nutritionists.
\end{abstract}

Conclusion: Several factors were shown to influence the incidence of DMT 2 control attitude, exercise, knowledge, age, family support, and how to take the medicine.

Keywords: Factors controlling; DMT 2 failure; Sampit Central Kalimantan

Penulis korespondensi : dianasuryabima@gmail.com 


\section{Pendahuluan}

Diabetes melitus adalah penyakit menahun yang ditandai oleh kadar glukosa darah melebihi normal dan gangguan metabolisme karbohidrat, lemak dan protein yang disebabkan oleh defisiensi hormon insulin secara relatif atau absolut. Beban global diabetes menurut WHO adalah 135 juta, dimana beban ini diperkirakan akan meningkat terus menjadi 366 juta orang setelah 25 tahun kedepan (2025). ${ }^{1,2}$ Penelitian epidemiologi menunjukkan adanya kecenderungan peningkatan angka insiden dan prevalensi DMT2 diberbagai penjuru dunia, termasuk Indonesia. World Health Organization (WHO), dari 57 juta angka kematian di dunia pada tahun 2008, 36 juta (63\%) disebabkan oleh penyakit tidak menular.

Empat penyakit tidak menular utama adalah penyakit kardiovaskular (48\%), kanker $(21 \%)$, penyakit pernapasan kronis $(12 \%)$ dan diabetes $(3,5 \%)$. World Health Organization WHO) memperkirakan angka kematian akibat penyakit tidak menular mencapai 55 juta orang di tahun 2030. Angka kematian penyakit tidak menular antara 3070 tahun adalah tertinggi di sub-Sahara Afrika, Eropa Timur dan sebagian Asia, termasuk di Indonesia. ${ }^{3} \mathrm{HbA} 1 \mathrm{c}$ digunakan sebagai alat kontrol untuk menilai pengendalian DMT 2, khususnya status glikemik. Hal ini disebabkan karena HbAlc dapat menggambarkan konsentrasi glukosa rata-rata 60-90 hari sebelum pemeriksaan, sehingga dapat memberikan gambaran dari status DMT2 secara lebih konsisten. Status glikemik terkendali, ditandai dengan kadar $\mathrm{HbA1c}$ dalam batas yang ditentukan oleh konsensus. ${ }^{4,5}$ Paul Immet memberi gambaran tentang prevalensi DM didunia sudah mencapai $5,1 \%$ dari orang dewasa, yaitu sekitar 194 juta penduduk usia antara 20-79 tahun pada tahun 2005, jumlah penderita DMT2 diperhitungkan akan naik lagi menjadi 333 juta $\left(6,3 \%\right.$ pada orang dewasa). ${ }^{6}$

Organisasi Kesehatan Dunia (WHO), beban global DM 135 juta ini diperkirakan akan meningkat terus menjadi 366 juta orang setelah 25 tahun ke depan (2025). DM tertinggi di dunia ada di India 31,7 juta, Cina
20,8 juta, Amerika Serikat 17,7 juta, Indonesia 21,3 juta. Asia (2025) diperkirakan mempunyai populasi diabetes terbesar di dunia yaitu 82 juta orang serta akan meningkat menjadi 366 juta orang setelah 25 tahun. Laporan Internasional Diabetes Federation (IDF) tahun 2010, penderita DM di Uni Eropa 31\%, Uni Emirat Arab 8,7\%. Penelitian secara epidemiologi di berbagai daerah di Indonesia yang dilaksanakan pada tahun 2007 menunjukkan bahwa DM tertinggi ada di Kalimantan Barat 11,1\%, Maluku Utara 11,1\%, Riau 10,4\%, Nanggroe Aceh Darussal am 8,5\% dan Bali 3\%. Sekitar 90-95\% penderita DMT2 sering diderita oleh orang dewasa yang berusia lebih dari 30 tahun dan cenderung semakin parah secara bertahap. Klasifikasi DM yang dianjurkan oleh PERKENI adalah yang sesuai dengan anjuran klasifikasi DM American Diabetes Association. DMT2 atau disebut juga dengan insulin requirement (membutuhkan insulin) adalah mereka yang membutuhkan isulin sementara atau seterusnya. Prankeas tidak menghasilkan cukup insulin agar kadar gula darah normal, oleh karena badan tidak dapat respon terhadap insulin.

Penyebab tidak hanya satu yaitu akibat resistensi insulin yaitu banyaknya jumlah insulin tapi tidak berfungsi. Kekurangan insulin atau karena gangguan sekresi atau produksi insulin. DMT2 menjadi semakin umum oleh karena faktor risiko yaitu obesitas dan kurang berolahraga. Faktor yang mempengaruhi DM yaitu usia lebih dari 65 tahun, obesitas, riwayat keluarga ${ }^{8}$ DM sangat berpotensi merusak pembuluh darah kecil dan pembuluh darah besar. Jika merusak pembuluh darah kecil, maka dapat menimbulkan kerusakan pada retina mata, gingal, dan penyakit saraf. Risiko terkena pembuluh darah besar maka penyakit kardiovaskular meningkat antara 2-4 kali lipat dan risiko terkena serangan stroke naik hingga dua kali lipat. Organ dapat terkena komplikasi kronis diabetes yaitu pembuluh darah jantung (penyakit jantung koroner), pembuluh darah dalam otak (berhenti aliran darah yang menuju otak dapat menimbulkan 
kematian), pembuluh darah kaki, pembuluh darah alat kelamin, pembuluh darah mata, Pembuluh darah ginjal (nefropati diabetik). ${ }^{9}$

\section{Metode}

Penelitian ini menggunakan desain kasus kontrol diperkuat dengan data kualitatif. Jumlah responden sebanyak 122 responden, meliputi 61 kasus dan 61 kontrol yang diambil secara consecutive sampling. Instrument penelitian adalah kuesioner wawancara. Analisis data secara univariat, bivariat (chi square) dan multivariat (logistic regression $){ }^{10}$
Hasil

Karakteristik subyek penelitian meliputi domisili/alamat,usia, jenis kelamin, status menikah, pekerjaan, pendidikan terakhir dan sosial ekonomi. Variabel independen yang dianalisis secara bivariat adalah faktor usia, lama menderita, jenis kela min, merokok, tingkat pendidikan, tingkat sosial ekonomi, pengetahuan, sikap, praktik, pola diit, obesitas, cara minum obat, kegiatan berolahraga, peran serta/dukungan keluarga, stres/depresi, edukasi oleh dokter/ internis dan edukasi dari ahli gizi.

Tabel 1. Distribusi responden menurut usia, jenis kelamin, tingkat pendidikan dan pekerjaan pada kelompok kasus dan kontrol

\begin{tabular}{|c|c|c|c|c|}
\hline \multirow{2}{*}{ Karakteristik Subyek } & \multicolumn{2}{|c|}{ Kasus } & \multicolumn{2}{|c|}{ Kontrol } \\
\hline & $\mathrm{n}$ & $\%$ & $\mathrm{n}$ & $\%$ \\
\hline \multicolumn{5}{|l|}{ 1. Usia } \\
\hline$<40$ thn & 24 & 39,3 & 42 & 68,9 \\
\hline$\geq 40$ thn & 37 & 60,7 & 19 & 31,1 \\
\hline \multicolumn{5}{|l|}{ 2. Jenis kelamin } \\
\hline Laki-laki & 28 & 45,9 & 35 & 57,4 \\
\hline Perempuan & 33 & 54,1 & 26 & 42,6 \\
\hline \multicolumn{5}{|l|}{ 3. Tingkat pendidikan } \\
\hline Rendah & 6 & 9,8 & 12 & 19,7 \\
\hline Menengah & 31 & 50,8 & 32 & 52,5 \\
\hline Tinggi & 24 & 39,3 & 17 & 27,9 \\
\hline \multicolumn{5}{|l|}{ 4. Pekerjaan } \\
\hline PNS & 38 & 62,3 & 30 & 49,2 \\
\hline ABRI & 0 & 0 & 1 & 1,6 \\
\hline Pensiun & 16 & 26,2 & 23 & 37,7 \\
\hline Peserta & 7 & 11,5 & 7 & 11,5 \\
\hline
\end{tabular}

Tabel 2. Rangkuman hasil analisis bivariat berpengaruh terhadap kegagalan pengendalian diabetes melitus kasus dan kontrol

\begin{tabular}{lrrr}
\hline \multicolumn{1}{c}{ Variabel } & OR & \multicolumn{1}{c}{$95 \%$ CI } & Nilai p \\
\hline Pengetahuan(-) & 0,35 & $0,16-0,74$ & 0,009 \\
Kegiatan berolahraga(-) & 0,30 & $0,14-0,67$ & 0,004 \\
Usia $\geq 40$ thn & 0,29 & $0,13-0,61$ & 0,002 \\
Pola minum obat(-) & 0,25 & $0,12-0,54$ & 0,001 \\
Peran serta/dukungan keluarga(-) & 0,25 & $0,12-0,56$ & 0,001 \\
Sikap(-) & 0,21 & $0,07-0,62$ & 0,005 \\
\hline
\end{tabular}




\section{Pembahasan}

\section{Faktor-faktor yang terbukti berpengaruh terhadap ketidakberhasilan pengendalian DMT 2}

Hasil analisis diketahui bahwa sikap yang tidak adekuat terhadap DM berisiko 34,46 kali lebih besar dibandingkan dengan sikap adekuat ( $95 \%$ CI : 4,45 - 266,85). Hasil indepth interview menyatakan bahwa kurangnya kesadaran akan hidup sehat. Hal ini sesuai dengan pendapat Jazilah, dkk menemukan faktor perilaku mempunyai hubungan yang bermakna dengan kontrol gula darah dan mempunyai faktor risiko terhadap tidak terkontrolnya glukosa darah dengan OR untuk sikap sebesar 2,58 (95\% CI : $1,08-6,16){ }^{11}$

Kebiasaan berolahraga yang tidak baik memiliki risiko 8,73 kali lebih besar untuk tidak berhasil dalam pengendalian status glikemik dibandingkan diabetesi dengan kebiasan olahraga yang baik $(95 \% \mathrm{CI}$ : 2,36 - 32,25). Hasil indepth interview menyatakan bahwa tidak adanya waktu dan malas. Hal ini sesuai dengan pendapat Handayani, Suharyo dan Henry dalam studinya mengenai faktor-faktor risiko terjadinya DM di Semarang menunjukan bahwa faktor-faktor risiko yang berpengaruh terhadap kejadian DMT2 adalah aktifitas olahraga yang kurang (OR 9.1 ; 95\% CI 1.5 $53,5) .{ }^{12}$

Pengetahuan yang tidak adekuat terhadap DM berisiko 8,49 kali lebih besar dibandingkan dengan individu yang pengetahuan adekuat (95\% CI : 1,55946,314). Hasil Hasil indepth interview menyatakan bahwa kurangnya informasi dan edukasi. Penelitian Jazilah, dkk menemukan faktor perilaku mempunyai hubungan yang bermakna dengan kontrol gula darah dan mempunyai faktor risiko terhadap tidak terkontrolnya glukosa darah dengan OR untuk sikap sebesar 2,34 (95\% CI : 0,986$5,57) \cdot{ }^{11}$

Usia $\geq 40$ tahun mempunyai risiko tidak terkendalinya status glikemik sebesar 5,93 kali lebih besar dibandingkan yang memiliki riwayat penyakit $<$ dari 40 , dengan (95\% CI : 1,88 - 18,67). Handayani, Suharyo dan Henry dalam studinya mengenai faktor-faktor risiko terjadinya DM di Semarang menunjukan bahwa faktorfaktor risiko yang berpengaruh terhadap kejadian DMT2 adalah umur $>40$ tahun (OR $7,5 ; 95 \%$ CI $2.6-20,9){ }^{12}$

Dukungan keluarga mempunyai risiko tidak terkendalinya status glikemik sebesar 5,26 kali lebih besar dibandingkan dengan yang mendapat dukungan keluarga $(95 \% \mathrm{CI}=1,72-16,06)$. Hasil indepth interview menyatakan bahwa kurangnya kesadaran anggota keluarga. Hal ini tidak sesuai dengan pendapat Gina, menciptakan hubungan kemitraan yang baik antara penderita dan keluarga. ${ }^{13}$

Cara minum obat yang tidak adekuat mempunyai risiko 3,55 kali lebih besar untuk ketidakberhasilan pengendalian status glikemik dibandingkan dengan cara minum obat yang adekuat (95\% CI : 1,30 - 9,58). Hasil indepth interview menyatakan bahwa selalu lupa, bila badan terasa sehat maka obat yang diberikan oleh dokter tidak dilanjutkan. Hal ini sesuai dengan penelitian Indah Norfiani Safitri (2013) ada perbedaan yang signifikan kepatuhan ditinjau dari locus of control $(F=3,405 \mathrm{p}=0,038)$. Subjek yang memiliki locus of control internal memiliki kepatuhan yang tinggi $(X 1=145,35)$ dibandingkan subjek yang memiliki locus of control eksternal powerful others (X2= 137,95) dan locus of control eksternal Chance $(\mathrm{X} 3=13,87) .{ }^{14}$

\section{Faktor-faktor yang tidak terbukti mem- pengaruh i ketidakberhasilan pengenda- lian DMT 2}

Hasil analisis bivariat dalam penelitian ini menunjukkan bahwa lama menderita tidak terbukti berhubungan dengan ketidakberhasilan pengendalian status glikemik dengan nilai $\mathrm{p}=0,255(\mathrm{OR}=1,65$; $95 \% \mathrm{Cl}: 0,78-3,51)$. Lamanya menderita DMT2 apabila tidak ditangani dengan serius akan mengakibatkan terjadinya komplikasi mikrovaskuler seperti penyakit ginjal kronis. ${ }^{15}$

Jenis kelamin tidak terbukti berhubungan dengan ketidakberhasilan pengen- 
dalian status glikemik dengan nilai $\mathrm{p}=0,277$ $(\mathrm{OR}=0,63 ; 95 \% \mathrm{Cl}: 0,30-1,28)$. Tidak adanya hubungan yang bermakna antara jenis kelamin laki-laki dengan perempuan dalam penelitian ini dikarenakan jumlah sampel antara kasus dan kontrol hampir sama, sehingga menimbulkan hasil yang tidak signifikan.

Merokok tidak terbukti berhubungan dengan ketidakberhasilan pengendalian status glikemik dengan nilai $\mathrm{p}=0,847(\mathrm{OR}=$ $1,16 ; 95 \% \mathrm{Cl} 0,54-2,47)$. Penelitian ini bertolak belakang dengan penelitian yang dilakukan oleh Handayani bahwa merokok merupakan faktor risiko terjadinya DMT2 dengan (OR 7,7 ; 95\% Cl 2.2-26,2).

Tingkat pendidikan tidak terbukti berhubungan dengan ketidakberhasilan pengendalian status glikemik dengan nilai $\mathrm{p}$ $=0,289(\mathrm{OR}=0,51 ; 95 \% \mathrm{Cl}: 0,17-1,54)$. Penelitian ini bertentangan dengan penelitian yang dilakukan oleh Jazilah dkk bahwa penderita DMT2 yang berpendidikan rendah mempunyai risiko tidak terkendalinya DMT2 3,87 kali dibandingkan dengan yang berpendidikan tinggi. ${ }^{11}$

Tingkat sosial ekonomi tidak terbukti berhubungan dengan ketidakberhasilan pengendalian status glikemik dengan nilai $\mathrm{p}$ $=1,000(\mathrm{OR}=2,03 ; 95 \% \mathrm{Cl}: 0,18-23,03)$. Penelitian ini sesuai dengan penelitian yang dilakukuan oleh San Antonio Heart Study, 1979-1982 menunjukkan bahwa peningkatan status sosial ekonomi dan migrasi ke komunikasi yang lebih baik dapatn mendorong pengurangan obesitas dan diabetes melitus tipe 2 dengan lebih progresif.

Praktik tidak terbukti berhubungan dengan ketidakberhasilan pengendalian status glikemik dengan nilai $\mathrm{p}=0,453$ (OR $=1,42 ; 95 \% \mathrm{Cl}=0,68-2,98)$. Penelitian ini bertentangan dengan penelitian yang dilakukan oleh Jazilah dkk dengan OR 14,23; 95\% Cl 4,830-41,929. ${ }^{11}$

Pola diit tidak terbukti berhubungan dengan ketidakberhasilan pengendalian status glikemik dengan nilai $\mathrm{p}=0,406$ (OR $=0,46 ; 95 \% \mathrm{CI}=50,84-1,47)$. Obesitas tidak terbukti berhubungan dengan ketidakberhasilan pengendalian status glikemik dengan nilai $\mathrm{p}=0,750(\mathrm{OR}=1,37 ; 95 \% \mathrm{Cl}$ : $0,38-$
4,91) ,bertolak belakang dengan penelitian yang pernah oleh Lustman PJ Anderson RJ, et al membuktikan bahwa depresi secara signifikan berhubungan dengan hiperglikemi $(Z=5,4 ; p=\varangle 0,0001){ }^{16}$

Edukasi dari dokter/internis tidak terbukti berhubungan dengan ketidakberhasilan pengendalian status glikemik dengan nilai $\mathrm{p}=1,000(\mathrm{OR}=1,00 ; 95 \% \mathrm{Cl}$ : 0,47-2,09). Penelitian ini berbeda dengan penelitian yang dilakukan oleh Lily kresnowati yang menyatakan bahwa edukasi dari dokter internis yang tidak adekuat dengan OR 8,35; 95\% Cl : 2,72-25,61. ${ }^{17}$

Edukasi dari ahli gizi tidak terbukti berhubungan dengan ketidakberhasilan pengendalian status glikemik dengan nilai $\mathrm{p}$ $=1,000(\mathrm{OR}=1,00 ; 95 \% \mathrm{Cl}: 0,38-2,60)$. Penelitian ini sesuai dengan pendapat Pieber bahwa keberhasilan penderita didasarkan atas model pemberdayaan (empowerment) penderita, bukan sekedar kepatuhan(compliance) belaka.

\section{Kesimpulan}

Berbagai faktor yang terbukti bermakna berpengaruh terhadap kegagalan pengendalian diabetes melitus tipe 2 adalah : Sikap yang tidak adekuat dipengaruhi oleh kurangnya kesadaran akan hidup sehat, kegiatan berolahraga yang tidak baik dipengaruhi oleh tidak adanya waktu, malas, pengetahuan tidak adekuat dipengaruhi oleh kurangnya informasi dan edukasi, usia $>40$ ta hun dipengaruhi oleh penurunan kemampuan sel pankreas dalam memproduksi insulin, peranserta/dukungan keluarga tidak adekuat dipengaruhi oleh kesadaran keluarga yang tidak terlalu peduli pada penderita dan cara minum obat yang tidak teratur dipengaruhi selalu lupa minum obat, sebagian masyarakat beranggapan apabila ada perubahan kearah sehat maka obat yang diberikan oleh dokter tidak dilanjutkan.

Berbagai faktor yang tidak terbukti bermakna berpengaruh terhadap kegagalan pengendalian diabetes melitus tipe 2 adalah : lama menderita, jenis kelamin, merokok, tingkat pendidikan, tingkat sosial ekonomi, 
pengaturan pola diit, obesitas, stres/depresi, edukasi dari dokter/internis dan edukasi dari ahli gizi.

Berdasarkan hasil persamaan regresi logistik probabilitas untuk ketidakbrhasilan pengendalian diabetes melitus tipe 2 sebesar $84,44 \%$.

\section{Ucapan Terimakasih}

Terimakasih kepada pihak Dinas Kesehatan Kabupaten Kota Waringin Timur, ASKES Cabang Sampit Kabupaten Kota Waringin Timur, RSUD Dr. Murjani Sampit Kabupaten Kota Waringin Timur Propinsi Kalimantan tengah yang telah memberi ijin dan membantu dalam proses pengumpulan data.

\section{Daftar Pustaka}

1. Capes, S. 2008. Preventing Coronary Artery Disease in People with Diabetes, Canadia Diabet Association; 21 (4).pp.27-35.

American Diabetes Association. 2005.

2. Standards of Medical Care for Patients With Diabetes Mellitus Position Statemen. Diabetes Care; S4-S42. pp. 29 (Supp 1).

3. Wild S, Roglic G, Gree A, Sicree R, King H. 2000. Global Prevalence of Diabetes Estimates for The Year 2000 and Projection for 2030.Diabetes Care;27.pp.103-105.

4. American Diabetes Association (ADA). 2004. Clinical Practice Recommendations. Screening for Type 2 Diabetes.

5. Koro CE, Bowlin SJ, et al. 2004. Preliminary Report : Glycemic Control From 1988 to 2000: Among U.S Adult Di- agnosed With Type 2 Diabetes. Diabetes; Vol 27 No. 1.

6. Perkeni. 2011. Konsensus engelolaan dan Pencegahan Diabetes Melitus Tipe 2 di Indonesia. PB.

Inzucchii S,.2003. Classification and

7. Diagnosis of Diabetes Mellitus, In: Elle nberg \& Rifkin's Diabetes Mellitus,6th. Companies, USA.
8. Szurkowska M, Szybiski Z, Nazim A, Szafraniec K, JedrychowskiW. 2001.

Prevalence of Type 2 Diabetes Mellitus in Population of Krakow. Pol Arch Med Wewn; 106.pp.771-779.

9. The Expert Committee on the Diagnosis and Classification of Diabetes Mellitus (ECDCDM). 2003. Report of the Expert Committee on the Diagnosis and Classification of Diabetes Mellitus. Greenberg RS,et al. 1993. Case Control Studies In: Medical Epidemiology.

10. USA:Prentice Hall International Inc, Appleton \& Lange.

J azilah, Wijono, P, Sudargo, T. 2003. Hubungan Tingkat Pengetahuan, Sikap

11. dan Praktik Penderita Diabetes Melitus Mengenai Pengelolaan Diabetes Melitus dengan Kendali Kadar Glukosa Darah. Sains Kesehatan.Vol 16. pp. 413-422.

Handayani SA, Suharyo, Henry, S.

12. 2003. F aktor-faktor risiko DMT2 di Semarang: Universitas Diponegoro.

13. Carey IM, DeWilde S, Richards N, Cook DG. 2005. Trend $s$ in the preval ence and management of diagnosed type 2 diabetes 1994-2001 in England and Wales. BMC Family Practice. pp. 14. 13.

Nofiani. 2013.Kepatuhan Penderita Diabetes Melitus Tipe 2 ditinjau dari Locus of Control. Malang: Fakultas Fiskologis.

15. American Diabetes Association, Diabetes Care. 2010. http: //c ar e diabetes journals,org/content/27/suppl 1/s5,

16. Lustman PJ, Anderson RJ, KE, De Groot M, Carney RM, Clouse PE. 2000. Depression and Poor Glycemic Control : Ameta-Analytic Review of. The Literature.

17. Lily K. 2008. Faktor-Faktor Internal dan Eksternal yang Mempengaruhi ketidakberhasilan Pengendalian Status Glikemik Pada Diabetes Mellitus Tipe 2 (Studi Kasus di TPK Yakes Telkom Area Jateng \& DIY . 